\title{
Analysis Of The Relationship Between Economic Cycle Swings And Adoption Rate Models Of Financial Innovation Diffusion
}

Acie S. Forrer, University of Maryland University College, USA Donald A. Forrer, Hodges University, USA

\begin{abstract}
The United States financial crisis, starting with the credit boom of 2007 and ending with the failure of Lehman Brothers in September 2008, has led to a loss of confidence in the United States financial system. The Financial Crisis Inquiry Commission indicated that the financial crisis affected over 26 million Americans. Many scholars have attributed the crisis to financial innovations, such as mortgage backed securities, adjustable rate mortgages and no-income verified loans, as key innovations that led to the market collapse. Financial innovations have had both positive and negative impacts on the financial industry. Providing a framework that describes the relationship between economic cycle swings and adoption rates of innovative financial instruments can provide greater stability and predictability in financial innovation diffusion, which can lead to more stable returns for shareholders and enhance the public interest through a healthy, innovative and more stable financial industry. An abbreviated evidence-based systematic review was completed on financial innovations that led to the financial crisis of 2007. The research suggests that there is an equilibrium period of time that financial organizations can adopt innovation to avoid unintended consequences like the recent financial crisis. Providing a framework of adoption time can demonstrate where financial innovations can be absorbed to provide the organization with the ability to financially innovate during pro and counter cyclical economic periods. Through an understanding of the timing of financial innovations as they occur in economic cycles, managers of financial organizations can choose the adoption period of time more carefully which could have averted the financial crisis that affected millions of Americans.
\end{abstract}

Keywords: Innovation Diffusion; Banking; Financial Innovation

\section{INTRODUCTION}

\section{Responses To The United States Financial Crisis}

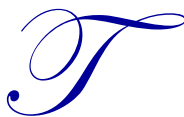

he United States financial crisis, starting with the credit boom of 2007 and ending with the failure of Lehman Brothers in September 2008, has led to a loss of confidence in the financial system (Kim, Koo\& Park, 2013). From 2008 to 2012, a total of 465 commercial banks failed (FDIC.gov). In an effort to regain consumer confidence, bank regulators have instituted regulations that constrict financial innovations and growth. The effect of tighter bank regulations impacts the ability of the banks to provide new credit facilities which has caused a credit crunch, leaving consumers fewer options to obtain new loans.

The Troubled Asset Relief Program (TARP) was introduced as a reactionary policy by the United States government to recapitalize the banking industry by providing much needed capital to banks to prevent insolvency (Carmassi, Gros, \& Micossi, 2009). TARP gave qualified U.S. bank's capital, with generous repayment terms over a long period of time (Carmassi et al., 2009). At the same time that TARP was implemented, U.S. bank regulators, at the recommendation of The Basel III Accord Committee, instituted a requirement for banks to maintain a capital adequacy ratio of thirteen percent, which was three percent higher than historically required levels (Carmassi et al., 
2009). The implementation of these two policies greatly impacted banks' ability to lend. U.S. banks that were unable to raise capital to meet the new requirements and the banks that did not receive TARP money were unable to lend, which forced them to shrink their asset size to comply with the new bank requirements for capital adequacy. Banks that did receive TARP monies did not want to lend to consumers, often saving their capital to acquire banks that could not survive the financial crisis (Docking, 2012)

Frame and White (2004) describe financial innovation as the ability of a financial institution to facilitate the allocation and positioning of economic resources over a period of time in an unstable or uncertain external environment by using knowledge obtained through internal and external sources. Financial innovations are primarily focused on profit generation for the organization and appear in the form of new products and modified practices and procedures aimed at maximizing shareholder wealth. The global financial crisis that started in the summer of 2007 has caused much debate about the causes of the financial market collapse with a significant interest in the influences of bankers and shareholders. The Financial Crisis Inquiry Commission indicated that the financial crisis affected more than 26 million Americans. However, the debate rarely addresses the role that financial innovations had on the financial crisis. Financial innovations in the banking industry are developed by financial organizations. These innovations occur rapidly and bank regulators require adequate time to understand the impact of the innovations before they can enact new regulations that can provide safety and financial soundness for the banking industry.

\section{Financial Innovation Diffusion}

Financial innovation has produced many positive contributions to the banking industry. Online banking, automated teller machines and lockbox services increased profit margins and provided consumers easier access to their funds (Costanzo, Keasey, \& Short, 2003). Financial innovations specific to the banking industry differ from innovations in other industries. The consequences of a bank's failure to assess the risk of adopting innovation extends beyond the financial firm to the local, national and global economy (Docking, 2012). Providing a framework that describes the relationship between economic cycle swings and adoption rates of innovative financial instruments can provide greater stability and predictability in financial innovation diffusion, which can lead to more stable returns for shareholders and enhance the public interest through a healthy, innovative and more stable financial industry. Financial Innovations have had both positive and negative impacts on the banking industry. New banking products, including online banking, mobile banking, and smart cards, have helped banks obtain a competitive advantage through innovative practices. Conversely, financial innovations that were introduced to the marketplace in 2007 included loan products which did not verify income or assets and negative amortizing loans, which had an adverse effect on long-term bank profitability. Innovation diffusion provides a unique insight into the role that financial innovation played in the financial crisis (Elenkov \& Petkova, 2010).

Davis (1962) describes innovation diffusion as the process where innovations are communicated within a social system over time. The rate of adoption of new innovations provides management the opportunity to decide whether to introduce innovations rapidly into the marketplace or take a slow approach to innovation adoption. Historically, bank shareholders support the rapid diffusion of innovation, whereas bank regulators support a slower diffusion process to ensure safety and soundness (Elenkov \& Petkova, 2010). Bank regulators are typically slow to react to financial innovations that have adverse effects on consumers. When regulators do react to ineffective innovations, they typically react with policies that restrict the innovativeness of the firm (Dockings, 2012).

Financial innovation diffusion is comprised of the development and introduction of a new product or process to the marketplace. The rate of absorption of the innovation can happen rapidly or over a long period of time (Gort \& Klepper, 1982). Frame and White (2004) indicate that financial innovations are diffused rapidly by management because shareholders are looking for an immediate return on their investment. Rapid diffusion of financial innovations provide quick profits to the organization and when pro cyclical market conditions exist, rapid innovations can offer a competitive advantage (Frame \& White, 2004).

Historically, bank regulators support slower diffusion of financial innovation (Frame \& White, 2004). Regulations can inhibit innovation. Banking regulations that disallow banks to own insurance companies can stifle innovative practices that could be obtained through merger or acquisitions between the banking and insurance industry. This can prompt banking organizations to circumvent regulation through innovative practice by 
introducing insurance type products into the marketplace (Frame \& White, 2004). Abrahamson's (1991) research suggested that when the diffusion of an innovation circumvents existing governing rules, the organization can be harmed in the long run. Banks that reaped the benefits of large profit windfalls because of innovative practices that were introduced into the market before they could be vetted by financial regulators have now seen substantial losses and depletion of their capital account (Carmassi, Gros, \& Micossi, 2009). Subsequently, bank regulators provide reactionary policies that constrict profitability through the increase in capital requirements. The conflict between bank shareholders and bank regulators is apparent in the research and understanding the relationship between them can provide a greater insight into the recent financial crisis.

\section{Conflicting Values Of Shareholder Vs. Stakeholder}

To understand the role that bankers and regulators had on the financial crisis, it is important to recognize the influence of shareholders and stakeholders on profit behavior. In a capitalist society, the primary responsibility of the organization is to maximize shareholder wealth (Friedman, 1970). Adam Smith's views on laissez-faire capitalism (1776), which is the foundation of economic theory in the United States, state that if each individual looks out for their own best interest, then it benefits the group as a whole. Friedman's (1970) theory on creating shareholder wealth expands Smith's original work (1776) by stating that it is the moral obligation of the organization to increase shareholder and stakeholder wealth. Friedman's (1970) research defined the government's role as one that collects money from the organization in the form of taxes and to provide social services. According to Friedman, shareholders are individuals that have a financial investment in an organization in hopes of getting a positive economic return on their investment. A widely accepted interpretation of stakeholders refers to shareholders, customers, employees, suppliers and the local community (Freeman, 1984). According to stakeholder theory, managers of an organization have two distinct responsibilities - to ensure that no ethical violations occur to any stakeholder and to maximize profitability to the firm while ensuring that the organization will be a going concern (Freeman, 1984). For the purposes of this article, shareholders are defined as the owners of the financial organization and stakeholders are defined as the government regulators that regulate the financial organizations' safety and soundness practices.

Bank mangers walk a delicate tightrope consisting of improving financial performance and negotiating complex government regulations (Charan \& Freeman, 1979). In the banking industry, bank shareholders are looking to maximize their own interest in the form of a return on their investment. Bank stakeholders, such as federal regulators, are trying to protect the consumer from an unstable banking environment that can result from unsafe banking policies, as we have learned from TARP instituted after the financial crisis to recapitalize banks. The U.S. taxpayer has a direct stake in the financial performance of the banking industry. Freeman (1984) outlined the paradox that exists between management's view toward both shareholders and stakeholders. Management has a contractual obligation to adhere to the interest of their shareholders and a moral responsibility to take their stakeholders into account. Verrett (2011) uses agency theory to explain the conflict between shareholders and regulators. His research indicates that shareholders are trying to maximize profits and regulators are looking out for the public's interest.

Shareholders are concerned that their interest is not being adequately protected when managers are faced with choosing between corporate governance and shareholder interest. Smith (1776) noted that potential negligence can occur when managers are not being vigilant with the shareholders' money and should always put the shareholders' interest first. Bank managers also have competing stakeholder interest which implies that the corporation is a social entity that must follow societal norms when making business decisions (Freeman, 1984).

Shareholders have learned that they can modify managers' behaviors through corporate incentives (Letza, Sun, \& Kirkbride, 2004). Prior to the financial crisis that started in 2007, bank managers were making bonuses at record levels. Financial innovations, such as credit default swaps (CDS), mortgage back securities (MBS), and collateralized debt obligations (CDO), were creating wealth for both shareholders and bank managers at confounding intensities (Verett, 2011).

Conversely, bank examiners were not able to keep up with the rapidness of the financial innovations that were occurring and were using the financial stability of the marketplace as the barometer for initiating new bank 
regulations (Kane, 2012). The combination of financial innovation and stakeholder apathy helped create the worst financial crisis in the United States since the 1930's. Two prevalent economic strategies illustrate the economic environment that both bank shareholders and stakeholders were conflicted with prior to the financial crisis.

\section{Economic Cycles}

Historically, bank performance follows the cyclicality of the financial marketplace (Englund, 1989). Bank shareholders typically choose pro cyclical strategies, deciding to be more aggressive during positive economic periods and more conservative during economic downturns. This strategy conflicts with the bank regulators' view, which supports a counter cyclical approach to financial distributions and capital adequacy (Cai \& Wheale, 2009). The conflicting interest between shareholders and regulators can cause large swings in the innovativeness of the firm when market conditions change.

Pro cyclicality strategies support the position that banks should keep lower levels of capital during positive economic times and higher levels of capital during economic instability. Pro cyclicality strategies also supports the practice that shareholders should be able to receive financial distributions when financial times are good and replenish the capital accounts when financial times are negative. As the recent financial crisis demonstrates, shareholders spent earnings, leaving most banks close to insolvency.

Shareholder value maximization should be viewed as a long-horizon exercise (Vestergaard \& Wade, 2012). During positive economic conditions, it was common practice to hold lower capital levels in an effort to reward equity investors. This financial practice targeted developed countries, with investors interested in short-term gains more than long-term sustainability (Khorana \& Periman, 2010). When market conditions changed and banks needed to replenish their capital accounts, equity investors did not want to reinvest because they feared short term losses.

Vestergaard and Wade (2012) indicate that composition and trajectory of capital matter measures the quantity and quality of the capital injected in the financial institution. Historically, equity investors were the prominent drivers of financial growth in the banking sector. Due to the current financial crisis, a higher focus was placed on common equity versus investor equity. Investors are more favorable to banks that reinvest their earnings than banks that distribute their earnings to shareholders. Emerging markets tend to rely more heavily on common equity versus investor equity.

The counter cyclical strategy supports the concept that banks limit distributions to shareholders during positive economic times. This theory indicates that banks retain higher levels of capital in anticipation of future economic downturns. Vastergaard and Wade (2012) believe that taking a reactionary approach to capital adequacy is not sufficient and a more proactive approach is appropriate for today's economy. Their research indicates that capital adequacy ratios should be raised during economic prosperity. They believe that counter cyclicality strategies provides equilibrium, where credit expansion is controlled during positive economic times and contraction is limited during economic downturns.

Johnston (2009) indicated that commercial banks should prepare for a world of higher capital. The World Bank has determined that one of the major reasons for the financial crisis was inadequacy in capital. Typically, most financial regulators considered ten percent Tier 1 capital to be adequate capital. However, most financial analysts predict that the ratio will move to thirteen percent Tier 1 capital (Khorana \& Periman, 2010). This change could have a tremendous impact on the banking sector. New regulations requiring increased capital requirements could have a negative impact on earnings. If this negative impact occurs, investors may choose to invest in other industries, which would prompt a negative effect on the U.S. banking sector.

\section{Influence Of Capital Inadequacy}

Identifying a bank's capital position is an important component in understanding the risk that the organization is taking. Capital is the total amount of excess funds that exist when a bank's assets exceed its deposits and liabilities. This surplus provides a financial cushion to protect depositors and creditors in the unfortunate 
occurrence of a bank failure (Hill, 2011). In the apparent occurrence of a bank failure, the financial losses would first be funded from the shareholder's equity or capital and secondly from depositors.

Capital consists of two categories - Tier 1 consists primarily of investor's cash and retained earnings and is considered the highest quality of capital by bank regulators and Tier 2 consists primarily of non-cash items, such as subordinated debt and is considered less desirable by the bank regulators.

The Basel Committee and Congressional Oversight Committee were increasingly concerned with bank capital during the financial crisis (Khorana \& Perlman, 2010). The Basel Committee attempted to strengthen the global financial system by recommending recalibration techniques aimed at boosting capital adequacy requirements based on the most recent loss experience (Khorana \& Perlman, 2010). The Basel III capital adequacy framework has been adopted by many bank regulators throughout the world as the standard for adequate capital requirements (Johnston, 2009).

\section{Basel Committee: Impact On Capital Inadequacy}

In 1988, the Basel Committee introduced the Basel I Accord, which primarily focused on credit risk caused by borrower default (Cai \& Wheale, 2008). Basel I measures risk by taking a weighted average of total assets and dividing it by the amount of the bank's capital. Assets are placed into four categories based on risk. Category one consists of assets with zero risk, category two consists of assets with very little risk, category three consists of assets with medium risk, and category four consists of the remaining assets. The Basel Committee established a minimum ratio of 8 percent capital to total assets as a benchmark for the global banking community. The minimum capital adequacy requirement established by Basel was thought to be adequate to protect consumers from bank failures.

In 2004, the Basel Committee recognized that Basel I did not consider risk such as liquidity, interest rate risk, and operational risk. They introduced Basel II in an attempt to remedy the aforementioned risks. Basel II Accord, commonly referred to as Basel II, is comprised of a three-pillar system, focusing on capital adequacy, supervisory review, and market discipline. The minimum acceptable capital ratio remained at 8 percent. The major changes included the addition of a supervisory component and the requirement for the banks to be more transparent to investors and the global financial community (Cai \& Wheale, 2008).

The overall objective of the Basel III Committee is to create a balance between loan growth and market stability (Vestergaard \& Wade, 2012). This committee recognized that loan growth was increasing at a rate that far outpaced capital contribution. This was one of the major factors that contributed to the financial crisis. In an effort to contract loan growth, Basel III introduced new measures that increased capital and slowed down loan growth in September 2010.

The Basel Committee historically follows a pro cyclic approach to capital adequacy, choosing to tighten capital requirements when the economy is weak and loosen capital requirements when the economy improves. This approach benefits the shareholder who receives distributions during economic prosperity and has no binding obligation to replenish capital when the market is weak. The World Bank and governments are responsible to fund depleted capital accounts when investors decide not to reinvest in the bank. When the United States government is forced to provide bail-out money to the banking industry, a negative effect to stakeholders occurs. Conversely, counter cyclical policies promote the increase of capital to higher levels above the standard 8 percent during good economic times. These policies would support raising capital adequacy limits between 12 and 14 percent during prosperous times. Counter cyclicality policies keep more of the shareholders' money in the bank as a buffer and would protect the bank from becoming insolvent during economic downturns. The U.S. Shadow Financial Regulatory Committee has supported taking a counter cyclicality policy by recommending that an additional subordinated debt provision be added to promote market discipline (Cai \& Wheale, 2008). Subordinated debt holders have a fixed income claim which promotes monitoring of risk incurred by the bank. 


\section{Implications Of The Dodd-Frank Act}

The financial crises that occurred were mainly attributed to the housing market bubble caused by sub-prime lending practices of U.S. banks (Docking, 2011). The mortgage crisis was influenced by many factors, including deregulation of the banking industry, changes in accounting practices, innovative financial products such as derivatives, and primarily the deregulation of the Glass-Steagall Act of 1933 (Docking, 2012). The Glass-Steagall Act separated commercial and investment activities, allowing risk to be analyzed through two separate channels. The Gramm-Leach-Bliley Act (GLBA) of 1999 effectively repealed the Glass-Steagall Act and allowed commercial banks to start engaging in investment banking activities. GLBA allowed banks to establish financial holding companies capable of purchasing real estate for investment, underwriting, and selling insurance and securities. The primary effect of the GLBA was to create goliath banking institutions that became too big to fail (Docking, 2012).

Kim et al. (2013) researched a dataset of banks within 132 countries, measuring the effect that financial innovation has on government regulations. Research findings concluded that because of the rapidness of financial innovation, regulatory measures were critical to allowing the financial crisis to occur, specifically implicating that the deregulation of the Glass-Steagal Act was a contributory factor to the financial crisis. Carmassi, Gos, and Micossi (2009) supported this claim when they point to lax banking regulations that encouraged excessive leverage and cavalier investments made by senior management.

With the new freedom that bankers were experiencing from the deregulation of Glass-Steagal, bankers looked to predatory lending practices to boost earnings (Kane, 2011). They developed no income and no asset verification products which solely relied on an individual's credit score and loan to value of the real estate as the primary factor for approving the loan. In addition, they created products like negative amortization loans that would never get paid off and relied solely on real estate values improving for repayment. To avoid the risk of these risky transactions, bankers used their new freedom created by GLBA to securitize these loans and sell them to Wall Street. Wall Street packaged these loans as low risk owner-occupied residential portfolios and sold them to both domestic and foreign investors.

Fassin and Gosselin (2011) state that stakeholders are not viewed as equals by banks. They indicate the bank assigns a level of importance to each stakeholder. This approach is used to determine how much attention they provide each stakeholder. Special consideration is given to stakeholders, such as regulatory agencies, that can affect bank operations. Fassin and Gaooselin (2011) suggest that since the financial crisis of 2008, banks have exhibited self-serving behavior, focusing primarily on their own interest. This research concludes that many stakeholders were financially harmed by the lack of transparency in disclosure by the banks.

Behery and Eldomiaty (2010) conducted an empirical study that measured the relationship between a bank's stakeholders and the bank's performance. Their research indicated that in countries with a culture of stakeholder adherence, such as Japan, Germany and China, the relationship between stakeholder value and bank performance was very strong. The study also revealed that banks were more concerned with a class of stakeholders that they internally deemed important than with stakeholders that did not have an effect on their daily operations.

Concurrent with Basel III, The Dodd-Frank Act was established in 2010, which was a direct response by the United States Federal Government to unwind the chaos created by GLBA (Smith \& Muniz-Fraticelli, 2013). The Dodd-Frank Act expands government oversight to historically unregulated financial transactions, such as investment banking as well as thrift holding companies and their subsidiaries. To stabilize the financial marketplace, Dodd-Frank provides $\$ 700$ billion in funds through TARP to help re-capitalize banks. In addition, Dodd-Frank provides regulatory structure reform through a Congressional Oversight Panel, gives regulators the power to take corrective action to resolve problems in financial holding companies as well as limit incentives to bank executives that receive TARP monies, and, finally, provides consumer lending guidelines aimed at protecting consumers from predatory lending (Smith and Muniz-Fraticelli, 2013). 


\section{METHODOLOGY}

A rapid or abbreviated evidence-based systematic review was completed on financial innovations that led to the financial crisis of 2007. As defined by Gough (2007), this methodology works by bringing together different types of evidence to clarify what we know from existing research. Articles were categorized based on the type of financial innovation and the impact that the innovation had on the bank. In addition, the old bank regulation was listed and subsequent new regulation was provided. Table 1 portrays a pattern of literature used in the methodology used for this paper and categorizes the key literature that represented financial innovations that led to the financial crisis as well as the key regulation in place before the financial crisis and the financial regulation that replaced the inadequate regulation (Forrer, 2014).

Table 1: Categorization Of Literature

\begin{tabular}{|c|c|c|c|c|c|c|}
\hline Literature & & $\begin{array}{c}\text { Financial } \\
\text { Innovation }\end{array}$ & $\begin{array}{c}\text { Year of Financial } \\
\text { Innovation }\end{array}$ & $\begin{array}{c}\text { Prior } \\
\text { Regulation }\end{array}$ & $\begin{array}{c}\text { New } \\
\text { Regulation }\end{array}$ & $\begin{array}{c}\text { Negative Impact of } \\
\text { Financial Innovation }\end{array}$ \\
\hline $\begin{array}{l}\text { Kim et al., (2013), } \\
\text { Insterfjord (2004) }\end{array}$ & $\begin{array}{l}\text { 1) } \\
\text { 2) }\end{array}$ & $\begin{array}{l}\text { mortgage back } \\
\text { securities } \\
\text { derivatives }\end{array}$ & $\begin{array}{l}\text { 1) } 2002 \\
\text { 2) } 2003\end{array}$ & $\begin{array}{l}\text { Gramm-Leach- } \\
\text { Bliley Act }\end{array}$ & $\begin{array}{c}\text { Dodd-Frank } \\
\text { Act (2010) }\end{array}$ & Increased Leverage \\
\hline $\begin{array}{l}\text { Kane (2012), } \\
\text { Carmassi et al., } \\
\text { (2009) }\end{array}$ & 1) & $\begin{array}{l}\text { negative } \\
\text { amortization } \\
\text { loans } \\
\text { stated income/ } \\
\text { asset loans }\end{array}$ & $\begin{array}{l}\text { 1) } 2004 \\
\text { 2) } 2004\end{array}$ & $\begin{array}{l}\text { Gramm-Leach- } \\
\text { Bliley Act }\end{array}$ & $\begin{array}{c}\text { Dodd-Frank } \\
\text { Act (2010) }\end{array}$ & Asset Quality \\
\hline $\begin{array}{l}\text { Martin \& Parigi } \\
\text { (2011), Cai \& } \\
\text { Wheale, (2008) }\end{array}$ & 1) & $\begin{array}{l}\text { off-balance sheet } \\
\text { assets } \\
\text { pre-funded } \\
\text { interest reserves }\end{array}$ & $\begin{array}{l}\text { 1) } 2005 \\
\text { 2) } 2004\end{array}$ & Basel II & $\begin{array}{l}\text { Basel III } \\
(2010)\end{array}$ & $\begin{array}{l}\text { Balance Sheet } \\
\text { Integrity }\end{array}$ \\
\hline
\end{tabular}

By categorizing the literature based on the type of financial innovation and the impact the financial innovation had on the organization, it becomes clear that government stakeholders have implemented new regulations aimed specifically at correcting the negative impact of the financial innovation. It is also important to recognize the period of time it took from implementation of the financial innovation to regulation enacted to protect the public. As demonstrated in Table 1, it took anywhere from five to eight years for the regulators to react to the financial innovation. Both Dodd-Frank and Basel III were passed in 2010 which demonstrates that government regulators are not quick to react to new financial innovations, instead choosing to take a reactionary approach instead of being proactive.

Table 2 represents where pro cyclicality strategy and counter cyclicality strategy impact shareholders and stakeholders (Kim, 2012; Lee, 2010; adopted by Forrer, 2014). It also demonstrates the impact that Economic Cyclical Theory has on the diffusion of innovation. When market conditions are strong, innovation is adopted rapidly and when the economy is weak, innovation adoption is slow. Pro cyclical strategies follow economic cycles and allow shareholders to deplete capital accounts during economic prosperity and expect them to replenish capital accounts when the financial market changes. However, as noted earlier, shareholders fail to replenish when the market is prospering. Conversely, counter cyclical strategies support keeping a higher level of capital and limited shareholder distributions during prosperous times and using that excess capital as a buffer to shield off insolvency during economic downturns. Historically, banks have trouble recovering assets when the economy is weak. 
Table 2: Effects Of Economic Cycles

\begin{tabular}{|c|c|c|}
\hline & Pro Cyclical Strategy & Counter Cyclical Strategy \\
\hline $\begin{array}{l}\text { Effects of Positive Economic } \\
\text { Trends }\end{array}$ & Lower Regulatory Oversight & Increased Regulatory Oversight \\
\hline $\begin{array}{l}\text { Effects of Negative Economic } \\
\text { Trends }\end{array}$ & Increased Capital & Capital Inadequacy \\
\hline Effect on Shareholders & $\begin{array}{l}\text { - Increase wealth during economic } \\
\text { prosperity } \\
\text { - Dependent on shareholder re- } \\
\text { investing during economic downturn } \\
\text { - Increase leverage }\end{array}$ & $\begin{array}{l}\text { - Greater stability for bank } \\
\text { - Limited shareholder distributions } \\
\text { - Inefficient use of capital during } \\
\text { prosperity }\end{array}$ \\
\hline Effect on Stakeholders & $\begin{array}{l}\text { - Inconsistent lending } \\
\text { - Financial bailouts } \\
\text { - Increased Taxes }\end{array}$ & $\begin{array}{l}\text { - Stronger domestic banking system } \\
\text { - Consistent lending }\end{array}$ \\
\hline Effects on Financial Innovation & - Rapid adoption & - Slower adoption \\
\hline
\end{tabular}

Elenkov et al. (2010) stated that the increased Tier 1 capital requirements closed down smaller financial institutions, unable to secure investors to satisfy the rising capital demand by financial regulators. This research provided an empirical study measuring the impact of increased capital requirements on the US banking sector. Findings suggest that smaller banks were unable to compete with increased capital requirements because of limited access to capital. Obstfeld et al. (2009) stated that this was an intentional act by the United States government when they developed TARP. The Federal Government was selective on determining which banks were able to borrow money from them. According to research, many smaller banks were turned down for TARP assistance, forcing them to rely on the open market for capital (Obstfeld et al., 2009).

Understanding the pace at which financial organizations should adopt innovations provides insight into the relationship between the timing of financial innovations as they occur in economic cycles and innovation adoption rates. Represented in Figure 1 is Rogers (1962) seminal work on innovation diffusion that provides a framework to understand the adoption of financial innovations.

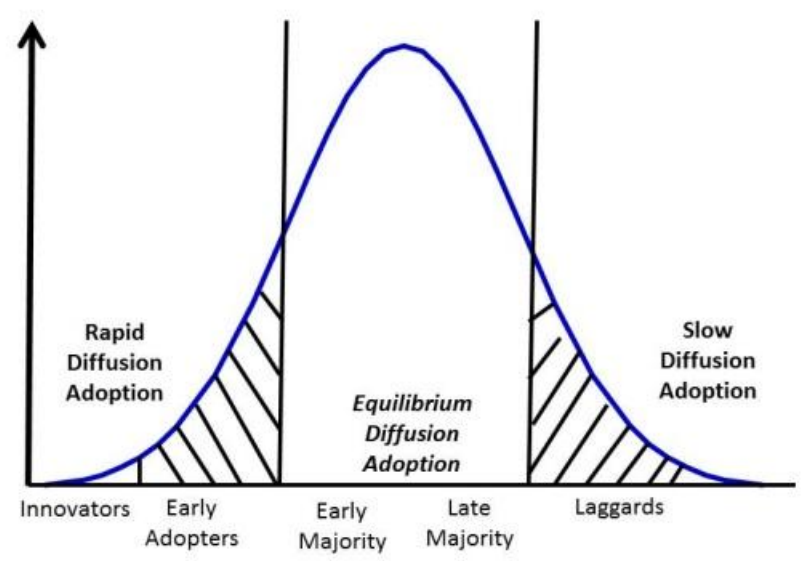

Figure 1: Adaption Of Rogers (1962) Bell Curve Of Innovation Diffusion, Indicating The Equilibrium Innovation Diffusion Adoption Of Financial Innovations (Forrer, 2014)

Rogers' research (1962) ascertains that individuals experience five stages of accepting a new innovation, including knowledge, persuasion, decision, implementation, and confirmation. If the innovation is adopted, then it is spread out through various communication channels (Rogers, 1983). Rogers (1962) created a bell curve that measures when an innovation is adopted over a set period of time. Rogers (2002) advanced his model of innovation 
diffusion by researching the effect that preventative innovations have on an organization. His research supports a specific action-taking place to avoid unwanted financial conditions. Preventative innovations typically diffuse slowly because of potential unwanted consequences that can happen over time. His research indicated that diffusion of preventative innovations can occur more rapidly when peer networks are adopted in the early stage, which can gauge the effect of the innovation on the public interest. This seminal work in innovation diffusion provides a construct that can be used to measure when innovations are adopted.

Pearson and Warther's (1997) research indicates that the equilibrium for adoption of financial innovations is at a point between early adaptors and laggards. They believe that financial innovations can end so abruptly that there is too much risk in adopting innovations at the end of the bell curve. Their research concluded that firms that adopted innovations at the end of the wave often lost money. Docking (2012) indicated that banks that entered the market late in the adoption of mortgage-backed securities were unable to package and sell these innovative securities in the secondary market when the market went down and they were left with risky adjustable rate mortgages, which subsequently defaulted and negatively affected banks' earnings. Early adopters faced different challenges when adopting financial innovation. According to Pearson and Warther (1997), early adopters enter the market too quickly with financial innovations which can lead to innovations that do not provide the outcome the firm is looking for. The recent banking crisis is an example of early adopters rapidly getting into the marketplace without truly understanding the implications of their innovations.

Figure 1 provides a potential equilibrium period time that financial innovations can be adopted to avoid entering the market too quickly or risk lagging behind the competition and entering the market right before the economical usefulness of the innovation expires. Frame and White (2004) researched eight studies of diffusion of financial innovations to ATM machines and concluded that financial innovations were most effective when they were adopted at the early and late majority stages of Rogers' (1962) bell curve of innovation diffusion. Rogers' (1983) research on the adoption of innovation is consistent with the findings of Frame and White (2004). Akhavein, Frame, \& White (2005) researched the adoption of credit-scoring commercial applicants in ninety-nine large banks between 1990 and 1997. Their research indicated that banks that have adopted credit scoring in the early and late stages of innovation adoption were more successful in the adoption of credit scoring because they were able to develop the infrastructure needed to adequately manage the adoption of the innovation. Figure 1 is a valuable conceptual graphic that can be used within cyclicality theory of economics to determine the most efficient time period to adopt financial innovations.

\section{Conceptual Framework}

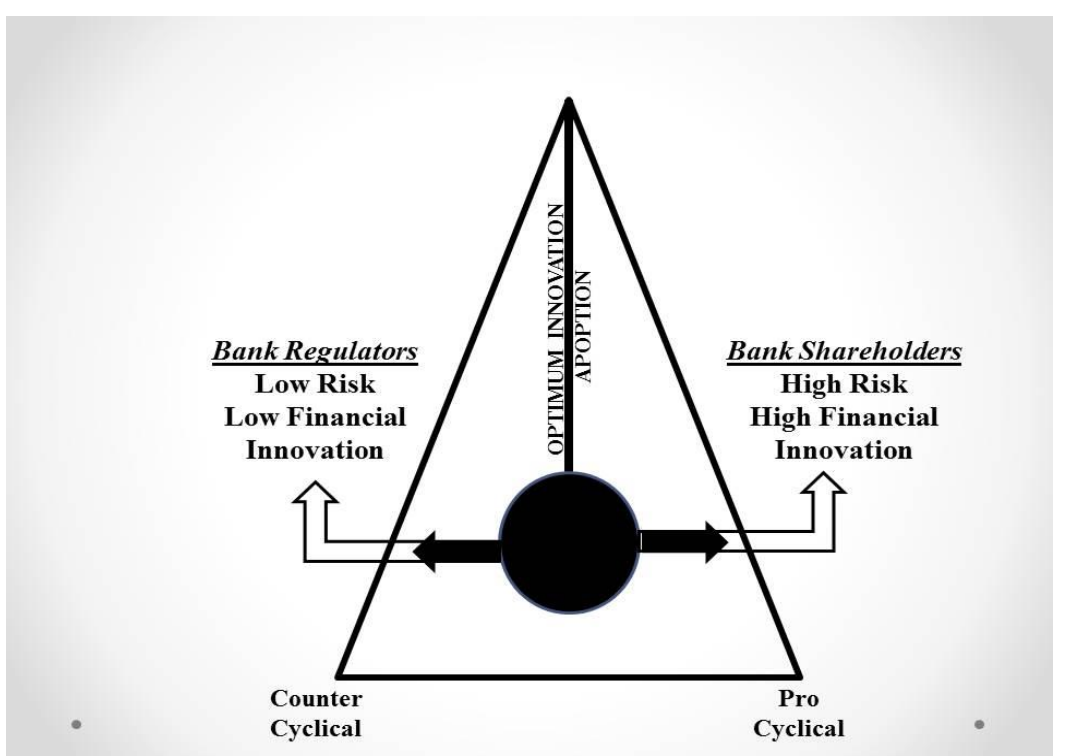

Figure 2: Portrayal Of The Relationship That Exists Between Pro And Counter Cyclical Market Conditions In Relationship To The Adoption Of Financial Innovation (Forrer-2014) 
As demonstrated in Figure 2 during pro-cyclical economic times, shareholders are willing to take more financial risk and produce innovative products and services that correlate with the risk they are willing to take. Carmassi et al. (2009) describe this phenomenon as the belief that economic conditions will always remain strong. Conversely, bank regulators subscribe to counter-cyclical economic strategies that pull bank shareholders to a lower innovative state and away from too much risk. The deregulation and lax oversight by bank regulators allowed the pendulum to swing to the right causing an unsafe adherence to risk, and when the financial market crashed, the pendulum swung too far to the left causing banks to lose their ability to innovate and maintain profitability.

Shareholder value maximization should be viewed as a long-horizon exercise. During positive economic conditions, it was common practice to take greater risk when innovating in an effort to reward equity investors. This phenomenon is represented when the pendulum swings too far to the right. Conversely, bank regulators are protecting the public interest and select a more conservative and reactionary approach. When market conditions weaken, bank regulators constrict innovation through regulation and the pendulum swings too far to the left.

Figure 2 provides a conceptual graphic that illustrates a framework that defines the relationship between economic swings and adoptive rates of innovative financial instruments. As market conditions strengthen, shareholders are willing to take greater risk in the speed at which they adopt new innovations. When market conditions weaken, bank regulators mandate bank policies that slow down the ability of banks to adopt innovations. Financial innovations that impact the financial market can have major successes and devasting failures (Person \& Warther, 1997). Pearson and Warther (1997) believes that the boom and crash cycle of financial innovations is the result of a well-functioning market that can be managed by knowing the equilibrium point in time to adopt innovations.

\section{LIMITATIONS}

The recent financial crisis in the U.S. was first initially examined in the literature approximately four years ago and is still undergoing analysis and empirical validation. Limitations to the provided research include the lack of empirical data to validate a precise period of time to adopt financial innovations. The scope of the research was general in nature and information gathered was reliant on existing literature which lacked specificity. The pace of innovation adoption was researched across a range of financial institutions and future research on the effect that the type of financial organization has on the rate and adoption of innovation could provide greater insight into the relationship that exists between financial innovations and adoption rates. Future research, specifically measuring the relationship between timing of financial innovation as they occur in economic cycles and the pace of innovation adoption, could help overcome some of these limitations.

\section{DISCUSSION AND IMPLICATIONS}

U.S. banks have shareholders and stakeholders that have competing views on risk. When the financial economy is strong, commercial banks use innovative capabilities to enhance shareholder wealth through financial innovation. Conversely, when the financial economy is under stress, commercial banks abandon their innovativeness and conform to bank regulator guidelines, resulting in diminished financial innovation. The literature supports the claim that bank regulators take a reactionary approach to financial innovations, choosing to wait and see if there is a negative impact instead of taking a proactive approach. This can be attributed to the rapidness of financial innovations that are usually less incremental and more radical in nature. Basel III and DoddFrank are both bank regulations designed to protect the consumer and provide regulators with guidelines to manage bank risk. Both regulations have accomplished the goal of measuring risk but have also contracted the financial innovativeness of the financial organization.

The research also supports the claim that financial innovations occur rapidly and can have a short shelf life. Providing a framework of adoption time can demonstrate where financial innovations can be absorbed to provide the organization with the ability to financially innovate during pro and counter cyclical economic periods.

Bank shareholders and financial regulators conflict on their views of adoption rates of financial innovations. Bank shareholders apply pressure to their managers to rapidly adopt innovations to improve 
profitability. Bank regulators prefer that financial innovations be adopted at a slower rate to ensure the solvency of the bank in an effort to protect the public interest. Adopting financial innovations at the early and late majority stage of adoption can help ensure that financial innovations are providing adequate profitability to bank shareholders, while protecting the public interest by properly vetting the innovation.

Theoretical implications include providing an understanding of the relationship between the timing of financial innovations as they occur in economic cycles within the construct of the pace of the adoption of the innovation. Understanding the impact that cyclical conditions have on the relationship of shareholders and stakeholders can allow scholars the ability to advance management's thought on the pace that financial innovations should be adopted.

Financial managers walk a delicate tightrope consisting of improving financial performance and negotiating complex government regulations. Developing financially innovative products allows managers the ability to improve profitability and the franchise value of their firm. By understanding the pace that financial innovations should be adopted, financial managers will be able to avoid the pendulum swings in their ability to innovate caused by economic cyclicality. The practical implications would be greater stability and predictability in financial innovation diffusion, which could lead to more stable returns for shareholders and enhance the public interest through a healthy, innovative and more stable financial industry

\section{AUTHOR INFORMATION}

Acie Forrer is a Senior Vice President and Senior Lender for First American Bank in Naples, Florida. Acie is ABD in a Doctoral program at the University of Maryland - University College and is in the final stages of his dissertation on the effects of technological change on organizational commitment and job satisfaction.

Don Forrer has a Doctorate in Business Administration and serves as a Professor in the MBA/MPA program at Hodges University (formerly International College) in Naples, Florida. Additionally, Don is the CEO/President of Cybernetics Concepts, a management consulting team specializing in utility economics. He served as a management professor at Troy University, Strayer University, Embry-Riddle University, Central Michigan University \& International College. He has lectured on management topics in Taiwan, Japan, Guam, and throughout the United States.

\section{REFERENCES}

Abrahamson, E. (1991). Managerial Fads and Fashions: The Diffusion and Reflection of Innovations. Academy of Management Review, 16(3), 586-612. doi:10.5465/AMR.1991.4279484.

Akhavein, J., Frame, W., \& White, L. J. (2005). The Diffusion of Financial Innovations: An Examination of the Adoption of Small Business Credit Scoring by Large Banking Organizations. Journal Of Business, 78(2), 577-596.

Cai, Z., \& Wheale, P. (2009). Managing Efficient Capital Allocation with Emphasis on the Chinese Experience. Journal of Business Ethics, 87111-135.

Carmassi, J., Gros, D., \& Micossi, S. (2009). The Global Financial Crisis: Causes and Cures. Journal of Common Market Studies, 47(5), 977-996. doi:10.1111/j.1468-5965.2009.02031.x.

Charan, R., \& Freeman, R. (1979). Stakeholder negotiations: Building bridges with corporate constituents. Management Review, 68(11), 8.

Costanzo, L. A., Keasey, K. K., \& Short, H. (2003). A Strategic Approach to the Study of Innovation in the Financial Services Industry: The Case of Telephone Banking. Journal Of Marketing Management, 19(3/4), 259-281.

Docking, D. (2012). The 2008 Financial Crises and Implications of the Dodd-Frank Act. Journal of Corporate Treasury Management, 4(4), 353-363.

Englund, P. (1989). Monetary Policy and Bank Regulations in an Economy with Financial Innovations. Economica, 56(224), 459-472.

Elenkov, D., \& Petkova G. I. (2010). Effects of the Financial Crisis on Leadership in the Banking Sector. Journal of International Finance \& Economics, 10(1), 69-73. 
“FDIC.gov," Federal Deposit Insurance Company, accessed March 20, 2014. http://www.fdic.gov/.

Fon Hilmarsson, H. (2011). The Bretton Woods Institutions in a Post Crisis World and the Increasing Influence of Emerging Market Economies. Human Resources: The Main Factor of Regional Development, (4), 59-73.

Frame, W., \& White, L. J. (2004). Empirical Studies of Financial Innovation: Lots of Talk, Little Action? Journal of Economic Literature, 42(1), 116-144.

Freeman, R. E. (1984). Stategic management: A stakeholder approach. Boston, MA: Pitman.

Friedman, M. (2008). The social responsibility of business is to increase its profits. In J. Burchell (Ed.), The corporate social responsibility reader (pp. 84-89). New York, NY US: Routledge/Taylor \& Francis Group.

Friedman, A. L., \& Miles, S. (2002). Developing Stakeholder Theory. Journal of Management Studies, 39(1), 1-21.

Greenbaum, S. I. (1996). Twenty-five Years of Banking Research. FM: The Journal of The Financial Management Association, 25(2), 86.

Jagtiaini, J., Saundersb, S., \& Udellb, G. (2009). The effect of bank capital requirements on bank off-balance sheet financial innovations: Journal of Banking \& Finance.

Johnston M. (2008). Extending the Basel II approach to estimate capital requirements for equity investments. Journal of Banking And Finance, 331177-1185. doi:10.1016/j.jbankfin.2008.12.018.

Jones, T. M. (1995). Instrumental Stakeholder Theory: A Synthesis of Ethics and Economics Academy Of Management Review, 20(2), 404-437. doi:10.5465/AMR.1995.9507312924.

Letza, S., Xiuping, S., \& Kirkbride, J. (2004, July). Shareholding Versus Stakeholding: a critical review of corporate governance. Corporate Governance: An International Review. pp. 242-262. doi:10.1111/j.14678683.2004.00367.x.

Khorana, A., \& Perlman, M. (2010). Replenishing the Banking Sector: Managing Bank Capital in the Post-Crisis World. Journal of Applied Corporate Finance, 22(3), 94-111. doi:10.1111/j.1745-6622.2010.00294.x.

Kane, E. (2012). Missing elements in US financial reform: A Kübler-Ross interpretation of the inadequacy of the Dodd-Frank Act: Journal of Banking \& Finance.

Krosner, R. S. (1999). Can the Financial Markets Privately Regulate Risk?. Journal of Money, Credit \& Banking (Ohio State University Press), 31(3), 596-618.

Martin, A., \& Parigi, B. M. (2013). Bank Capital Regulation and Structured Finance. Journal of Money, Credit \& Banking (Wiley-Blackwell), 45(1), 87-119. doi:10.1111/j.1538-4616.2012k.00563.x.

Mizen, P. (2008). The Credit Crunch of 2007-2008: A Discussion of the Background, Market Reactions, and Policy Responses. Review (00149187), 90(5), 531-567.

Persons, J., \& Warther, V. (1997). Boom and bust patterns in the adoption of financial innovations. Review of Financial Studies, 10(4), 93.

Rogers, E. M. (1962). Diffusion of Innovation. New York: Free Press.

Rogers, E. M. (1983). Diffusion of Innovation. ( $2^{\text {nd }}$ ed.). New York: Free Press.

Rogers, E. M. (2002). Diffusion of Preventative Innovations Addictive behaviors 27(6), 989 -993.

Scannella, E. (2012). Capital Regulation and Italian Banking System: Theory and Empirical Evidence. International Journal of Economics \& Finance, 4(2), 31-43. doi:10.5539/ijef.v4n2p31.

Smith, Adam. (1976). [1776]. An Inquiry into the Nature and Causes of the Wealth of Nations [WN]. The Glasgow Edition of the Works and Correspondence of Adam Smith, Bol. 2, eds. R. H. Campbell, and A. S. Skinner. Oxford: Oxford University Press.

Smith, L., \& Muniz-Fraticelli, V. M. (2013). Strategic shortcomings of the Dodd-Frank Act. Antitrust Bulletin, 58(4), 617-633.

Schumacher, R. (2012). Adam Smith's theory of absolute advantage and the use of doxography in the history of economics. Erasmus Journal For Philosophy \& Economics, 5(2), 54-80.

Verret, J. W. (2011). Separation of Bank and State: Consolidating Bailed-Out Companies into the U.S. Debt Ceiling and Government Financial Statements. Brigham Young University Law Review, 2011(2), 391.

Vestergaard, J., \& Wade, R. (2012). The Governance Response to the Great Recession: The "Success" of the G20. Journal of Economic Issues (M.E. Sharpe Inc.), 46(2), 481-490. 